\title{
Fractal Kinetics of COVID-19 Pandemic
}

\author{
Anna L. Ziff ${ }^{\text {a }}$, \& Robert M. Ziff ${ }^{\text {b }}$ \\ Received: 17 February 2020 • Accepted: 5 March 2020
}

\begin{abstract}
The classic epidemiological approach in the study of a pandemic such as COVID-19 disease is to quantify a reproduction number and infection time. However, this assumption leads to exponential growth, and while the growth rate is high, it is not following exponential behavior. One approach that is being used is to simply keep adjusting the reproduction number to match the dynamics. Other approaches use rate equations such as the SEIR and logistical models. Here we show that the current growth closely follows power-law kinetics, indicative of an underlying fractal or small-world network of connections between susceptible and infected individuals. Positive deviations from this growth law might indicate either a failure of the current containment efforts while negative deviations might indicate the beginnings of the end of the pandemic. We cannot predict the ultimate extent of the pandemic but can get an estimate of the growth of the disease.
\end{abstract}

Key-words: Fractal, Pandemic, Coronavirus, COVID-19, Infection, Kinetics, Logistical Models.

\section{Introduction}

The number of cases of novel coronavirus $2019 \mathrm{n}-\mathrm{CoV}$ (that produces the disease that has been named COVID-19) that started in China less than three months ago has been growing rapidly, pointing to a high infectivity. The mortality rate seems to fall somewhere between the common flu $(0.1 \%)$ and the SARs coronavirus (10\%). In Figs. $1 \mathrm{a}$ and $1 \mathrm{~b}$, we plot the total number of confirmed cases and total number of reported deaths, as a function of the

a Department of Economics, Duke University, Durham (USA) (D) ORCiD 0000-0001-64038516. ${ }^{b}$ Center for the Study of Complex Systems and Department of Chemical Engineering, University of Michigan, Ann Arbor (USA) (DORCID 0000-0002-9023-7508. Correspondence: Department of Economics, 213G Social Sciences, Box 90097, Duke University, Durham, NC 27708 (USA). Anna.ziff@duke.edu. 
number of days beginning with January 21, 2020, when the WHO first started reporting on this pandemic in its Situation Reports (World Health Organization, 2020). Both cases and deaths continue to grow at an alarming rate.

(a) Total Confirmed Cases

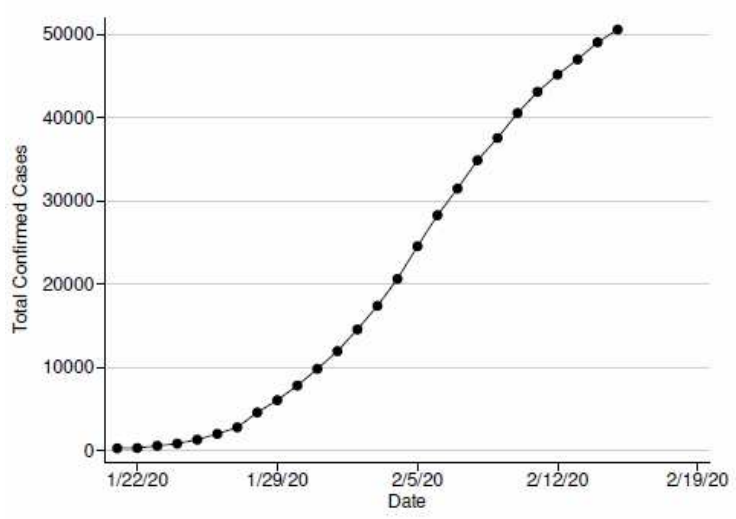

(b) Total Deaths

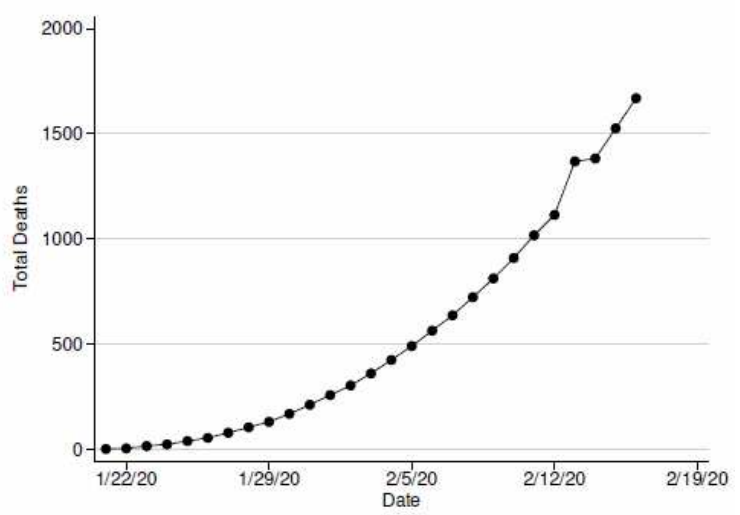

Figure 1. Raw Trends in COVID-19 Cases and Deaths. Note: Data from World Health Organization (2020).

In standard epidemiological analysis, one assumes that the number of cases in diseases like this one grows exponentially, based upon the idea of a fixed reproduction rate. If each person infects $\mathrm{n}$ other people where $n>1$ (the reproduction number), then the total number of cases should grow as $n^{t / \tau}=e^{a t}$, where $\tau$ is the incubation time, which depends on the characteristics of the particular disease. Several studies of COVID-19 have taken this approach to model the number of cases (e.g., Zhao et al., 2020). This assumes there is no inhibition due to the interaction with already infected people, quarantine, or other prophylactic measures.

While the data display large growth, they do not in fact follow exponential behavior. In the inset in Fig. 2 we show a log-normal plot of the mortality data, and the behavior is clearly not linear as it would be for exponential growth. In contrast, we find that the data are very well fit by assuming a power-law behavior with an exponent somewhat greater than two, as shown in the log-log plot in Fig. 2. The non-integer value of this power-law suggests a fractal type of behavior of the susceptibility mechanism, as we discuss below.

First we notice that the total number of deaths in Fig. 1b appear to be growing in a roughly quadratic form (see Tab. 1 in Appendix A for the estimates of the quadratic fit), while the number of confirmed cases shown in Fig. 1a appears to follow similar behavior but is slowing down in the last few 
data points. There could be measurement error due to multiple factors [some of these factors includes misrepresentation of the number of confirmed cases, and varying the criteria used for the identication of the disease. These have been discussed in news reporting (Wang, 2020, BBC, 2020). This analysis does not aim to quantify any intentional bias in the reported data]. Starting on February 7, those individuals who test positive for COVID-19 but show no symptoms are no longer being reported as confirmed cases (Cohen, 2020). We focus our analysis on deaths to circumvent some of the ambiguities of reporting confirmed cases, assuming that deaths are a more reliable indication of the extent of the disease. (However, there are reports that some deaths might be reported as due to other causes, such as severe pneumonia, and not attributed to this virus, so these numbers may also be inaccurate. Still, one set of data should give a good indication of the general trend of the pandemic.)

Growing as $t^{2}$ is what one would expect if a disease were growing in a population at the periphery of a compact region of infection. We believe that this is more likely than an exponential growth, because the number of susceptible individuals around an infected individual decays with time. Individuals already infected might face increased immunity and there are other individuals who might have had a mild infection that imparts immunity but without developing symptoms warranting testing. These various effects would inhibit the exponential growth of the virus.

We find that a power-law provides a better fit to the data than a simple quadratic, as postulated by Brandenburg (2020). In Fig. 2 we plot the number of total deaths vs. time on a log-log plot. As Fig. 3 shows, considering all of the time periods (excluding report \#24) from January 21 to February 15 (1-27 on the horizontal axis), the estimated coefficient is statistically indistinguishable from 2 . However, removing just the first period period (227 on the horizontal axis), the estimated coefficient is statistically larger than 2. As more periods are removed, the coefficient moves farther away from 2 . Even at this preliminary stage with few data points, this illustration suggests that a power-law fit is more appropriate than a quadratic one.

For illustration purposes, consider periods 8-27. The estimated coefficient is approximately 2.27 (the bootstrapped standard error with 5,000 replications is 0.014 ). This would imply that as the number of days of the pandemic increases by a factor of $2^{1 / 2.27}=1.357$, the number of cases will double. Thus, starting from day 27 (Feb. 16) with 1,669 deaths, the number of deaths will double to approximately 3,340 on day 37 (Feb. 22), and then double again to 6,680 on day 50 (March 10), and double again to 13,350 on day 67 (March 27). This is a large number of fatalities, but not nearly as large as if the growth were exponential. On the other hand, it is larger than some epidemiological models have been predicting.

The appearance of a fractional exponent and power-law behavior suggests an underlying fractal process. Based upon a kind of small-world 
interaction network where individuals have many local neighbors and occasional long-range connections (such as caused by people traveling on trains, boats and planes). The results imply that this network has an effective minimum path fractal dimension of 2.25. The implication is that the disease produces flares in which the growth is momentarily exponential, but then slows down until another flare-up. The averaged effect of this growth apparently yields a power-law.

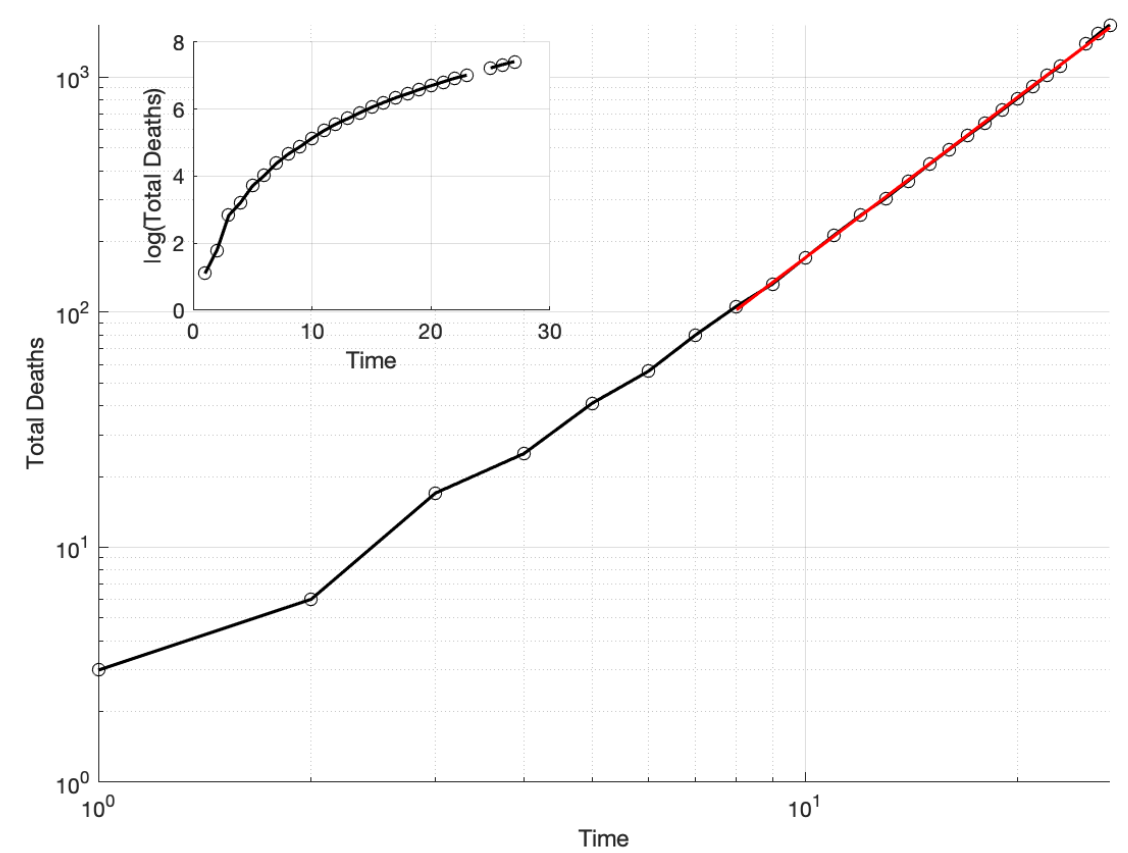

Figura 2. Total Deaths vs. Time (days since 1/21/2020) on a log-log plot (main plot) and log-normal plot (inset). Note: The red line in the large plot corrsponds to the power-law $t$ for periods $8\{27$, omitting 24 , i.e., $1 / 28 / 2020$ to $2 / 15 / 2020$, omitting spurious data for $2 / 13 / 2020$.

Data from World Health Organization (2020).

Wu et al. (2020) suggest that if the pandemic spreads into new cities, exponential growth like what happened in Wuhan in the early stages would occur. Hopefully, if this were the case, it would be quickly stopped and slower behavior would ensue. But our prediction of approximately 13,350 deaths by March 27 relies on the assumption that a new major outbreak will not happen. Hermanowicz (2020) and Roosa et al. (2020) have recently modeled the disease using a logistical and other growth models. These models are able to predict the ultimate number of cases, and find results in the range of 20,000 to 60,000 . We believe the numbers will be much greater, and expect a number of 
deaths in this range, if the fractal growth continues as it has for a few more months.

We have followed our prediction for several days and have found no marked change in behavior, except for the data from WHO Situation Report \#24, which gave an outsized jump of 254 cases to a total of 1,369 deaths. Reports stated that the data from China were incorrect that day because of double-counting of the results, but so far the WHO has not revised report \#24. Looking at the large deviation from our prediction in fact led us to suspect that that data point was an outlier at the time.

In recent days there has been a drop-off in the growth of new confirmed cases from China, suggesting an attenuation of the pandemic. We do not see that drop-off in the death rate. There are two possible explanations for this discrepancy: (1) the number of confirmed cases may be showing the variability as it has in the past, and the current numbers are not capturing the actual situation, or (2) the pandemic is indeed slowing down but it will take a while (perhaps a week) for that to show up in the fatality data. Of course, we hope the latter is the case, but are not entirely confident considering the history of the reporting problems concerning this pandemic.

Deviations above this power-law behavior might indicate that the pandemic is expanding from the current level of control, while deviations below might indicate that the disease is starting to fade. This analysis is early in the outbreak of COVID-19 and cannot predict the length of the outbreak nor the final fatality. However, it suggests that under current conditions, power-law growth better approximates the number of deaths than exponential growth, and may provide a tool to monitor whether a fundamental change is occurring. Hopefully, continued vigilance, timely testing, and careful care will end this scourge on humanity.

Note: The authors report no funding related to this research and have no conflicting financial interests.

\section{Appendix. Statistical Testing}

Table 1 lists the estimated coefficients from the regression Deaths $=\beta_{0}$ $+\beta$ 1time $+\beta_{2}$ time ${ }^{2}+\varepsilon$, where $\varepsilon$ is assumed to be time-independent and Normally distributed. We also report bootstrapped standard errors in brackets, which are more conservative in this small-sample context. See Efron and Tibshirani (1994) and Horowitz (2001) for introductions to the bootstrap method.

In Fig. 3, the confidence intervals are calculated as follows. First, robust standard errors are calculated to account for heteroskedasticity. These standard errors are more conservative, which is advantageous con- sidering our small sample size. Next, we calculate the critical value (the 95th quantile) 
from a $t$-distribution with $n-2$ degrees of freedom. The value $n$ changes with each point along the $x$-axis. As fewer periods are considered, the critical value increases. The degrees of freedom is a function of this $n$, but subtracting two to account for the fact that two parameters are estimated $\left(\beta_{0}, \beta_{l}\right)$. The standard errors are quite small for these calculations. Considering periods 2-27 produces a bootstrapped standard error of 0.033 , using 5,000 bootstrap replications.

Fig. 4 shows the estimated power-law exponents starting at period 8 and adding more periods forward. This mirrors our process of testing this model as more data were published on the number of deaths. The coefficient is stable. The confidence intervals are calculated analogously to those in Fig. 3. Note that data at period 24 are omitted due to probable inaccuracy, as we discuss above.

\begin{tabular}{lc}
\hline Time & 1.954 \\
& $(4.065)$ \\
& {$[4.504]$} \\
Time $^{2}$ & $2.123^{* * *}$ \\
& $(0.122)$ \\
& {$[0.132]$} \\
Constant & -39.46 \\
& $(23.84)$ \\
& {$[29.23]$} \\
\hline Observations & 36 \\
$R^{2}$ & 0.996 \\
\hline
\end{tabular}

Table 1. Estimates of a Quadratic Model of Deaths.

Note: Parametric standard errors are in parentheses, bootstrapped standard errors are in square brackets. We perform 5,000 replications. Data from World Health Organization (2020).

$$
*(\mathrm{p}<0.05), * *(\mathrm{p}<0.01), * * *(\mathrm{p}<0.001) .
$$




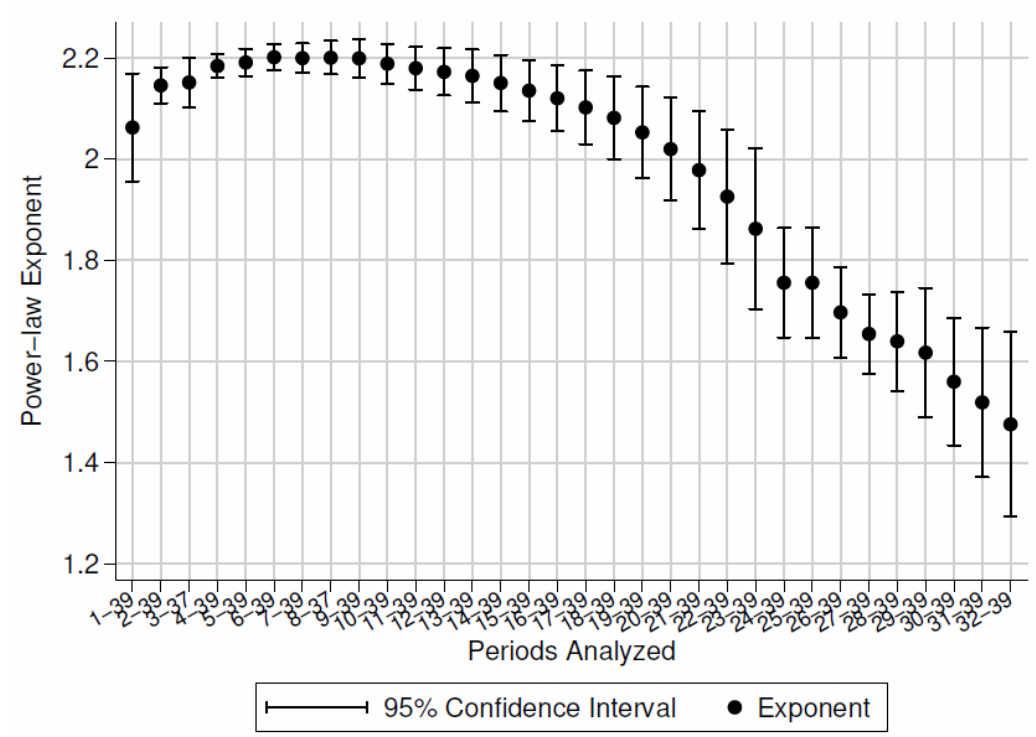

Figure 3. Power-law Coefficients, Dropping Earlier Periods.

Note: The coefficients are the ordinary least squares estimates of $\beta_{1}$ in the regression $\log$ (Deaths) $=\beta_{0}+\beta_{1}$ $\log ($ time $)+\varepsilon$ where $\varepsilon$ is unobserved and assumed to be time-independent and distributed according to a $t$ distribution with $n-2$ degrees of freedom. Robust standard errors are calculated for suggestive inference, considering the small sample size. Data from World Health Organization (2020).

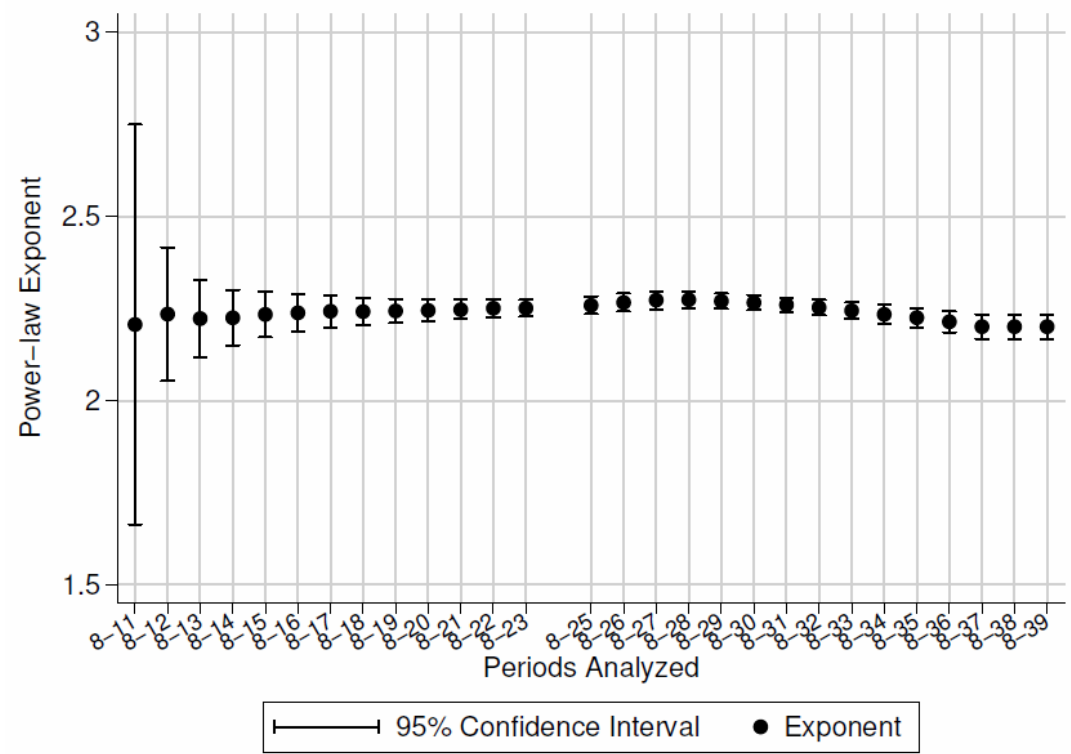

Figure 4. Power-law Coefficients, Dropping Later Periods.

Note: The coefficients are the ordinary least squares estimates of $\beta 1$ in the regression $\log ($ Deaths $)=\beta_{0}+\beta_{1}$ $\log ($ time $)+\varepsilon$ where $\varepsilon$ is unobserved and assumed to be time-independent and distributed according to a $t$ distribution with $n-2$ degrees of freedom. Robust standard errors are calculated for suggestive inference, considering the small sample size. Data from World Health Organization (2020). 


\title{
Update $3 / 1 / 20$
}

\section{Fractal Kinetics of COVID-19 Pandemic}

\begin{abstract}
Update] We give an update to the original paper posted on 2/17/20 - now (as of 3/1/20) the China deaths are rapidly decreasing, and we find an exponential decline to the power law similar to the that predicted by the network model of Vazquez (2006). At the same time, we see non-China deaths increasing rapidly, and similar to the early behavior of the China statistics. Thus, we see three stages of the spread of the disease in terms of number of deaths: exponential growth, power-law behavior, and then exponential decline in the daily rate.
\end{abstract}

Since the original posting of this paper on February 17 (which we are leaving intact below for comparison), the epidemic has fortunately slowed down considerably in China, and the current number of deaths there is 2,873 $(3 / 1 / 20)$. At the same time, the number of deaths outside of China (equal to 104 ) is growing very rapidly, almost exponentially. Therefore we now separate out the China cases from the non-China cases.

In Fig. 5 is a log-log plot of the deaths in China, showing a fit of the power-law behavior we saw before, fit for the days $1 / 28$ to $2 / 16$. It can be seen that the power-law we saw before continued for a few more days until about $2 / 20$, at which point the mortality began to decrease markedly.

In Fig. 6 we show the number of deaths in China each day, now plotted on a log-linear plot, and we see a sharp cutoff during the last week or so.

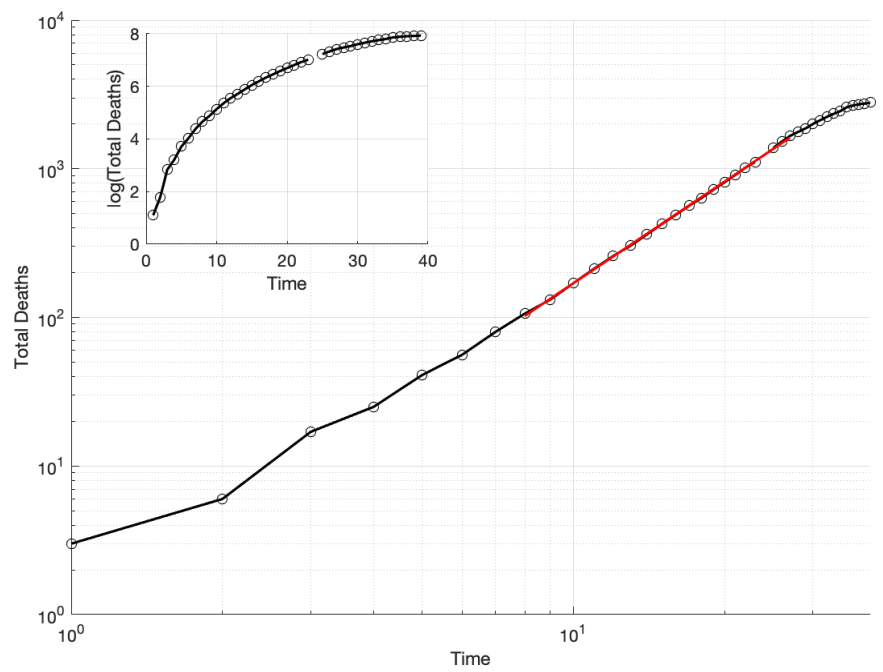

Figure 5. Deaths in China vs. Time (days since 1/21) on a log-log plot), and (inset) on a log-linear plot. 
Anna L. Ziff \& Robert M. Ziff, International Journal of Educational Excellence, (2020) Vol.

6, No. 1, 43-69. ISSN 2373-5929

DOI: $10.18562 /$ IJEE.053

The line is fit through the points filled in red, from day $8(1 / 28)$ to day 27 (2/16). Data from World Health Organization (2020).

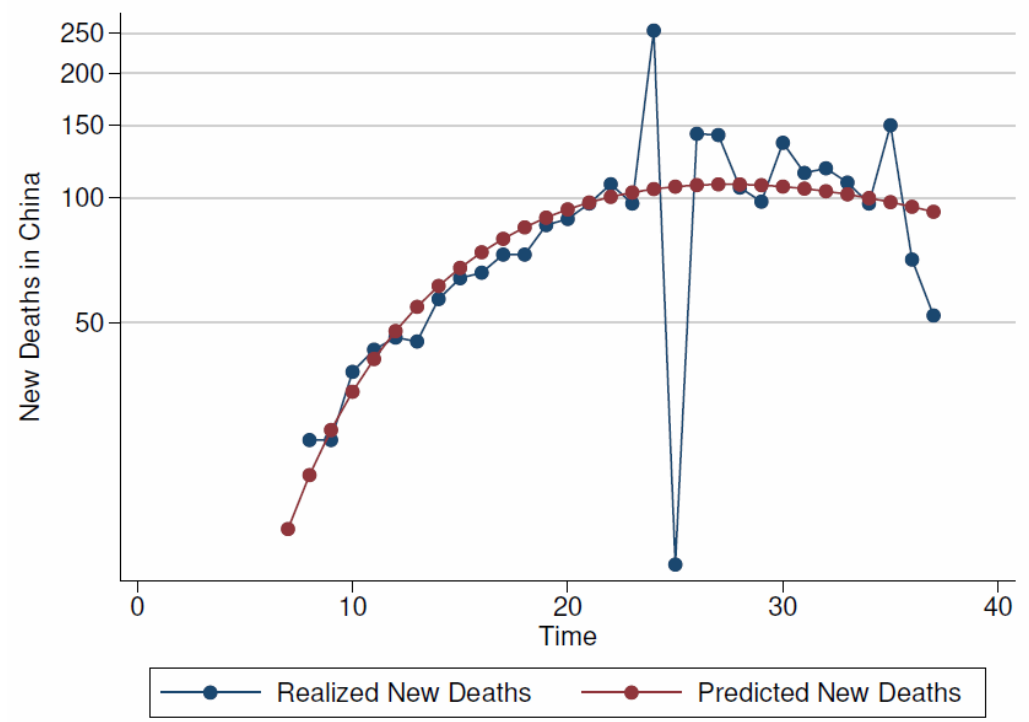

Figure 6. The daily number of deaths in China vs. Time (days since 1/21/2020) on a loglinear plot

The predicted new deaths is fit using the estimates reported in Tab. 2 . Data from World Health Organization (2020).

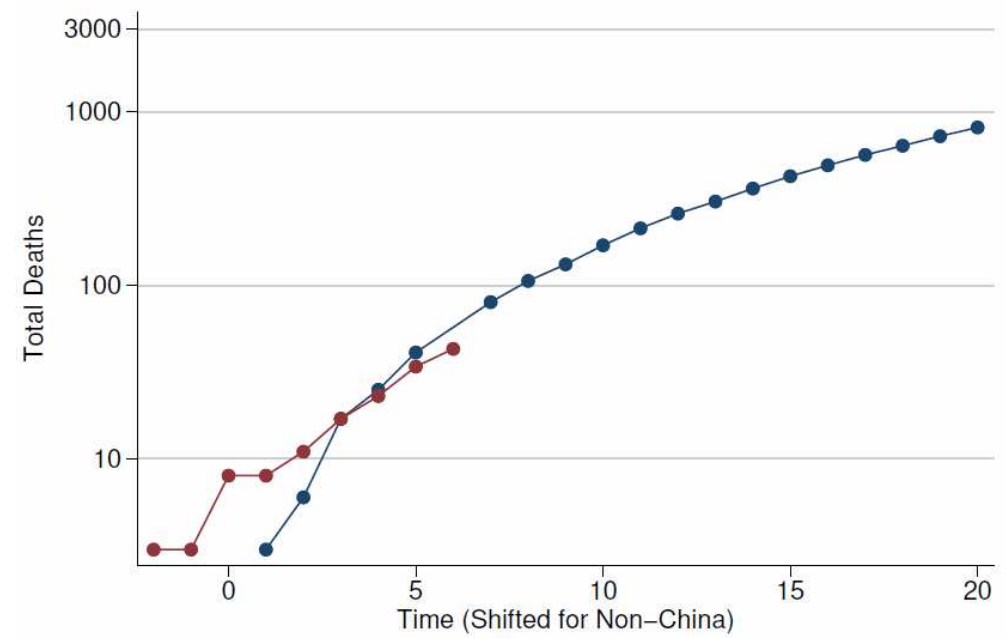

Figure 7. Total Deaths vs. Time, China and non-China on a log-linear plot 
To align the trends, we subtract 31 from the timing of the data points from outside of China. Data from World Health Organization (2020).

The power-law (fractal) behavior that we postulated is related to the properties of the networks that carry out the propagation of the disease. Vazquez (2006) developed a network model in which the daily number of new cases $n(t)$ in an epidemic follows a power-law with an exponential cutoff:

$$
n(t)=K t^{x} e^{-t / t_{0}}
$$

We have fit the data of China deaths to this function, and find $K=$ $0.0854, x=3.09$, and $\mathrm{t}_{0}=8.90$ days (the time constant of decay), and this fit is shown in Fig. 6. Note here that the exponent (3.09) is somewhat above the value 2.28 that we were finding by a fit of a simple power law.

This can be integrated to find the total number of deaths as a function of time, in terms of the Gamma function $\Gamma(x)$ and the incomplete Gamma function $\Gamma(\mathrm{a}, x)$ :

$$
N(t)=\int_{0}^{t} n(u) d u=K t_{0}^{1-x}\left(\Gamma(x+1)-\Gamma\left(x+1, \frac{t}{t_{0}}\right)\right)
$$

This plot is shown in Fig. 6, and we see a fairly good fit to the data.

The number of deaths outside of China has been growing rapidly. For several days it has been growing nearly exponentially, doubling every two to three days, but doe now appear to have slowed down a bit(although there are questions whether accurate data is being reported from one of the major hotspots, Iran). In Fig. 7, we show a log-linear plot of the deaths for the past 6 days, along with the deaths in China shifted by 31 days, and one can see somewhat similar behavior but fortunately with a downturn recently. We cannot predict any ultimate behavior for this behavior, but perhaps it will soon enter a power-law growth regime, before it enters the final stages.

It is likely, with the normal international travel in the months of Dcember and January, that the virus has been spread to many parts of the world, and cases have not been properly diagnosed. Thus we expect additional flair-ups to appear in different places in the world. But hopefully, with better understanding and appreciation of the disease, and appropriate responses, these flare-ups will be contained and a global pandemic can be averted.

Since we wrote our paper (and before as well), numerous papers have appeared modeling the epidemiology of the disease.

Li et al. (2020) confirm the power-law behavior we proposed for deaths in China, and also find power-law behavior (but with different exponents) for the number of infections and the number of recoveries. Fitting the number of 
cases to a quadratic on the log-log plot, they predicted an effective end of the epidemic around March 3 with a total of 83,000 cases, which so far has been well born out.

Numerous papers have considered compartment models and other methods to model the evolution of the epidemic Li (2020), Gamero et al. (2020), Rabajante (2020), Li and Feng (2020), Peng et al. (2020), Chen et al. (2020), Hu et al. (2020), Maier and Brockmann (2020), Li et al. (2020), Zhou et al. (2020), Xu et al. (2020), Liu et al. (2020). These tend to predict an Sshaped curve with a tapering off in the near future as is being seen. These models depend upon assumptions of the reproduction rate, incubation period, etc.

The authors thank Greg Huber, Ginestra Bianconi, and Youjin Deng for discussions and communications related to this work.

\section{References}

BBC (2020). Coronavirus: "Way too early” to predict end of outbreak, WHO says, February 2020. Retrieved from https://www.bbc.com/news/worldasia-china-51482994.

Brandenburg, A. (2020). Quadratic growth during the 2019 novel coronavirus epidemic. arXiv:2002.03638 [q-bio], February 2020. Retrieved from http://arxiv.org/abs/2002.03638.

Chen, B., Shi, M., Ni, X., Ruan, L., Jiang, H., Yao, H., Wang, M., Song, Z., Zhou, Q., \& Ge. T. (2020). Data Visualization Analysis and Simulation Prediction for COVID-19. arXiv:2002.07096 [physics, q-bio], February 2020. Retrieved from http://arxiv.org/abs/2002.07096.

Cohen, J. (20200). Scientists are racing to model the next moves of a coronavirus that's still hard to predict, February 2020. Retrieved from https:/www.sciencemag.org/news/2020/02/scientistsare-racing-model-next-moves-coronavirus-thats-still-hard-predict.

Efron B., \& Tibshirani, R. J. (1994). An Introduction to the Bootstrap. Boca Ratón, FL: CRC Press.

Gamero, J., Tamayo, J. A., \& Martinez-Roman, J. A. (2020). Forecast of the evolution of the contagious disease caused by novel coronavirus (2019nCoV) in China. arXiv:2002.04739 [q-bio, stat], February 2020. Retrieved from http://arxiv.org/abs/2002.04739. arXiv: 2002.04739.

Hermanowicz, S. W. (2020). Forecasting the Wuhan coronavirus (2019$\mathrm{nCoV}$ ) epidemics using a simple (simplistic) model - update (Feb. 8, 2020). Epidemiology, In Press, February 2020. doi: 10.1101/2020.02.04.20020461 Retrieved from http://medrxiv.org/ lookup/doi/10.1101/2020.02.04.20020461. 
Horowitz, J. L.. (2001). The Bootstrap. In S. Durlauf, L. Hansen, J. Heckman \& R. Matzkin (ed.), Handbook of Econometrics, volume 5, (pp. 31593228). New York: Elsevier, doi: 10.1016/S1573-4412(01)05005-X. Retrieved from https://linkinghub.elsevier.com/retrieve/pii/S157344120 $105005 X$.

Hu, Z., Ge, Q., Jin, L., and Xiong, M. (2020). Artificial Intelligence Forecasting of Covid-19 in China. arXiv:2002.07112 [q-bio], February 2020. Retrieved from http://arxiv.org/abs/2002.07112.

Li, J. (2020). A Robust Stochastic Method of Estimating the Transmission Potential of 2019-nCoV. arXiv:2002.03828 [physics, q-bio, stat], February 2020. Retrieved from http://arxiv.org/abs/2002.03828.

Li, M., Chen, J., \& Deng, Y. (2020). Scaling features in the spreading of COVID-19. arXiv:2002.09199 [physics, q-bio], February 2020. Retrieved from http://arxiv.org/abs/2002.09199.

Li, Q. \& Feng, W. (2020). Trend and forecasting of the COVID-19 outbreak in China. arXiv:2002.05866 [q-bio], February 2020. Retrieved from http://arxiv.org/abs/2002.05866.

Liu, Z., Magal, P., Seydi, O., and Webb, G. (2020). Predicting the cumulative number of cases for the COVID-19 epidemic in China from early data. arXiv:2002.12298 [math, q-bio], February 2020. Retrieved from http://arxiv.org/abs/2002.12298. arXiv: 2002.12298.

Maier, B. F., \& Brockmann, D. (2020). Effective containment explains subexponential growth in confirmed cases of recent COVID-19 outbreak in Mainland China. arXiv:2002.07572 [physics, q-bio], February 2020. Retrieved from http://arxiv.org/abs/2002.07572.

Peng, L., Yang, W., Zhang, D., Zhuge, C., \& Hong, L. (2020). Epidemic analysis of COVID-19 in China by dynamical modeling. arXiv:2002.06563 [q-bio], February 2020. Retrieved from http:// arxiv.org/abs/2002.06563.

Rabajante, J. F. (2020). Insights from early mathematical models of 2019$\mathrm{nCoV}$ acute respiratory disease (COVID-19) dynamics. arXiv:2002.05296 [q-bio], February 2020. Retrieved from http://arxiv.org/abs/2002. 05296. arXiv: 2002.05296.

Roosa, K., Lee, Y., Luo, R., Kirpich, A., Rothenberg, R., Hyman, J. M., Yan, P., \& Chowell G. (2020). Real-time forecasts of the 2019-nCoV epidemic in China from February 5th to February 24th, 2020. Infectious Disease Modelling, February 2020. doi: 10.1016/j.idm.2020.02.002. Retrieved from https://linkinghub. elsevier.com/retrieve/pii/S2468042 720300051 .

Vázquez. A. (2006). Polynomial growth in age-dependent branching processes with diverging reproductive number. Physical Review Letters, 96(3), 038702, Retrieved from http://arxiv.org/abs/condmat/0505116. 
Wang V. (2020). How Many Coronavirus Cases in China? Officials Tweak the Answer, February 2020. Retrieved from https:/www.nytimes.com/ 2020/02/12/world/asia/china-coronavirus-cases.html.

World Health Organization. Novel Coronavirus (2019-nCoV) situation reports. Technical Report 1-24, WHO, January 2020. Retrieved from https://www.who.int/emergencies/diseases/novel-coronavirus-2019/ situation-reports.

Wu, J. T., Leung, K., \& Leung, G. M., Nowcasting and forecasting the potential domestic and international spread of the 2019-nCoV outbreak originating in Wuhan, China: a modelling study. The Lancet, In Press, January 2020. doi: 10.1016/S0140-6736(20)30260-9. Retrieved from https: //linkinghub.elsevier.com/retrieve/pii/S0140673620302609.

Xu, X., Jiang, X., Ma, C., Du, P., Li, X., Li, S., Yu, L., Chen, Y., Su, J. Lang, G., Li, Y., Zhao, H., Xu, K., Ruan, L., \& Wei, W. (2020). Deep Learning System to Screen Coronavirus Disease 2019 Pneumonia. arXiv:2002.09334 [physics], February 2020. Retrieved from http://arxiv.org/abs/2002.09334. arXiv: 2002.09334.

Zhao, S., Lin, Q., Ran, J., Musa, S., Yang, G., Wang, W., Lou, Y., Gao, D., Yang, L., He, D., \& Wang, M. H. (2020). Preliminary estimation of the basic reproduction number of novel coronavirus (2019-nCoV) in China, from 2019 to 2020: A data-driven analysis in the early phase of the outbreak. International Journal of Infectious Diseases, In Press, January 2020. doi: 10.1016/j.ijid.2020.01.050. Retrieved from http://www.sciencedirect.com/science/article/pii/ S1201971220300539.

Zhou, Y., Chen, Z., Wu, X., Tian, Z., Cheng, L., \& Ye, L. (2020). The Outbreak Evaluation of COVID-19 in Wuhan District of China. arXiv:2002.09640 [physics, q-bio], February 2020. Retrieved from http://arxiv.org/abs/2002.09640.

C 2020 A. L. Ziff \& R. M. Ziff; licensee International Journal of Educactional Excellence, Universidad Ana G. Méndez (UAGM). This is an Open Access article distributed under the terms of the Creative Commons Attribution License (http://creativecommons.org/licenses/by/4.0), which permits unrestricted use, distribution, and reproduction in any medium, provided the original work is properly credited. 


\title{
Cinética fractal de la pandemia de COVID-19
}

\author{
Anna L. Ziff a , \& Robert M. Ziff ${ }^{\text {b }}$ \\ Received: 17 February 2020 • Accepted: 5 March 2020
}

\begin{abstract}
Resumen: El enfoque epidemiológico clásico en el estudio de una pandemia como la de la enfermedad COVID-19 consiste en cuantificar un número de reproducción y tiempo de infección. Sin embargo, esta suposición conduce a un crecimiento exponencial y, a pesar de que en el caso indicado la tasa de crecimiento es alta, se constata que no sigue dicho patrón. El enfoque utilizado por muchos autores es el de simplemente seguir ajustando el número de reproducción para que coincida con la dinámica. Otras posibilidades incluyen el uso de ecuaciones SEIR o modelos logísticos. Nosotros mostramos que el crecimiento actual se adapta a una ley de potencias, indicativa de un fractal subyacente o una red de conexiones entre individuos susceptibles e infectados. Las desviaciones positivas de esta ley de crecimiento podrían indicar un fallo de los esfuerzos de contención actuales, mientras que las desviaciones negativas pueden indicar el comienzo del fin de la pandemia. Actualmente no es posible predecir su alcance final de la epidemia, pero sí existe la posibilidad de estimar el crecimiento de la enfermedad.
\end{abstract}

Palabras Clave: Fractal, Pandemia, Coronavirus, COVID-19, Infección, Modelos Logísticos, Cinética.

\section{Introducción}

El número de casos del nuevo coronavirus 2019 n-CoV (que produce la enfermedad que ha sido denominada COVID-19) que comenzó en China hace menos de tres meses ha estado creciendo rápidamente, lo que indica una alta infectividad. La tasa de mortalidad parece situarse en algún punto entre la gripe común $(0,1 \%)$ y el coronavirus del SAR (10\%). En las Figs. 1a y 1b,

\footnotetext{
a Department of Economics, Duke University, Durham (USA) (DORCID 0000-0001-64038516. ${ }^{b}$ Center for the Study of Complex Systems and Department of Chemical Engineering, University of Michigan, Ann Arbor (USA) (D) ORCID 0000-0002-9023-7508. Correspondence: Department of Economics, 213G Social Sciences, Box 90097, Duke University, Durham, NC 27708 (USA). Anna.ziff@duke.edu.
} 
trazamos el número total de casos confirmados y el número total de muertes notificadas, en función del número de días a partir del 21 de enero de 2020, cuando la OMS comenzó a informar sobre esta pandemia en sus Situation Reports (World Health Reports, 2020). Tanto los casos como las muertes siguen creciendo a un ritmo alarmante.

(a) Total Confirmed Cases

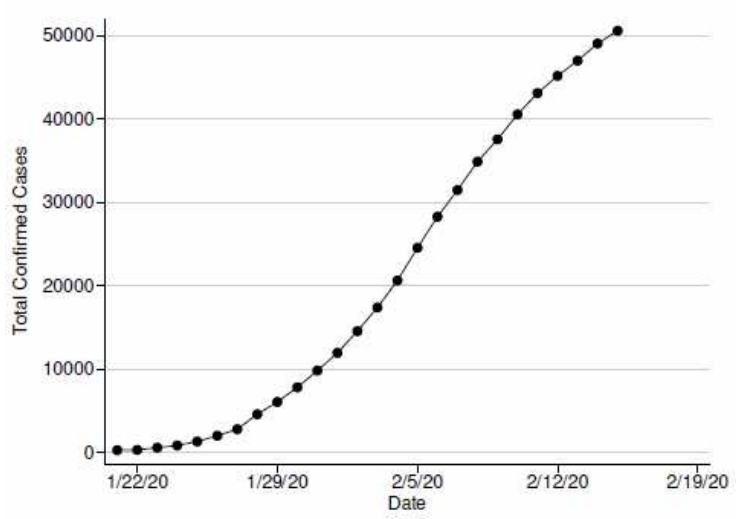

(b) Total Deaths

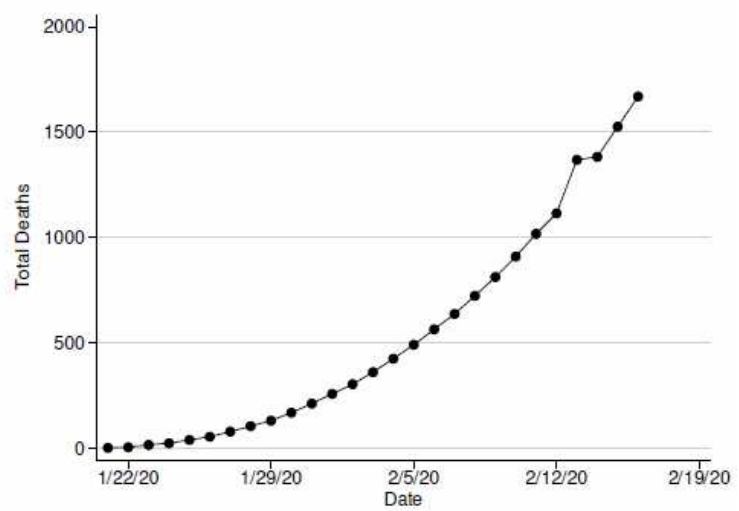

Figura 1. Tendencias en los casos y muertes de COVID-19. Nota: Datos de World Health Organization (2020).

En el análisis epidemiológico estándar, se supone que el número de casos en enfermedades como ésta crece exponencialmente, basándose en la idea de una tasa de reproducción fija. Si cada persona infecta a $n$ otras personas donde $n>1$ (el número de reproducción), entonces el número total de casos debería crecer como $n^{t / \tau}=e^{a t}$, donde $\tau$ es el tiempo de incubación, que depende de las características de la enfermedad en particular. Varios estudios de COVID-19 han adoptado este enfoque para modelar el número de casos (por ejemplo, Zhao et al., 2020). Esto supone que no hay inhibición debido a la interacción con personas ya infectadas, en cuarentena u otras medidas profilácticas.

Aunque los datos muestran un gran crecimiento, de hecho no siguen el comportamiento exponencial. En el recuadro de la Fig. 2 mostramos una gráfica logarítmica normal de los datos de mortalidad, y el comportamiento claramente no es lineal como lo sería para el crecimiento exponencial. Por el contrario, encontramos que los datos casan correctamente si se asume un modelo de ley de potencias de exponente mayor que dos, como se muestra en el gráfico principal de la Fig. 2. El valor no entero de esta ley de poder sugiere un tipo de comportamiento fractal del mecanismo de susceptibilidad, como discutimos a continuación. 
En primer lugar, observamos que el número total de muertes en la Fig. $1 \mathrm{~b}$ parece estar creciendo en una forma aproximadamente cuadrática (véase la Tabla 1 en el Apéndice para las estimaciones del ajuste cuadrático), mientras que el número de casos confirmados que se muestran en la Fig. 1a parecen seguir un comportamiento similar pero se está desacelerando en los últimos datos. Podría tratarse, no obstante, de un error de medición debido a múltiples factores [algunos de ellos incluyen la tergiversación del número de casos confirmados y la variación de los criterios utilizados para la identificación de la enfermedad. Estos han sido discutidos en los nuevos informes de noticias (Wang, 2020, BBC, 2020). Este análisis no tiene por objeto cuantificar ningún sesgo intencional en los datos notificados]. A partir del 7 de febrero, las personas que dan positivo para COVID-19 pero no muestran síntomas ya no se notifican como casos confirmados (Cohen, 2020). Centramos nuestro análisis en las muertes para evitar algunas de las ambigüedades de la notificación de los casos confirmados, suponiendo que las muertes son una indicación más fiable de la extensión de la enfermedad. Sin embargo, hay informes de que algunas muertes podrían ser recogidas como debidas a otras causas, como la neumonía severa, y no atribuidas a este virus, por lo que estas cifras también pueden ser inexactas. No obstante, este conjunto de datos deberían bastar para conocer la tendencia general de la pandemia.

Si la enfermedad estuviera creciendo en una población en la periferia de una región compacta de infección cabría esperar naturalmente un crecimiento de tipo $t^{2}$. Creemos que esto es más probable que un crecimiento exponencial, porque el número de individuos susceptibles alrededor de un individuo infectado se altera con el tiempo. Individuos ya infectados ofrecerían una mayor inmunidad, y por su parte individuos que hayan sufrido una infección leve pueden desarrollar inmunidad sin tener que desarrollar síntomas que justifiquen las pruebas. Todos estos efectos inhibirían el crecimiento exponencial del virus..

Se encuentra que una ley de potencias proporciona un mejor ajuste a los datos que una simple función cuadrática, como postuló Brandenburg (2020). Si en la Fig. 2 ya se presentaba el número de muertes totales en función del tiempo en un gráfico logarítmico, en la Fig. 3, considerando todos los períodos de tiempo (excluyendo el informe número 24) del 21 de enero al 15 de febrero (del 1 al 27 en el eje horizontal), el coeficiente estimado es estadísticamente indistinguible de 2. Sin embargo, eliminando solo el primer período (del 2 al 27 en el eje horizontal), el coeficiente estimado es estadísticamente mayor que 2. A medida que se eliminan más períodos, el coeficiente se aleja más de 2 . Incluso en esta etapa preliminar con muy pocos datos, la ilustración sugiere que una ley de potencias es más apropiada que una cuadrática.

Con fines ilustrativos, consideremos los períodos 8 al 27. El coeficiente estimado es aproximadamente 2,27. Esto implicaría que, a medida que la 
cantidad de días de la pandemia aumente en un factor de $2^{1 / 2,27}=1,357$, el número de casos se duplicará. Así, comenzando desde el día 27 (16 de febrero) con 1.669 muertes, el número de muertes se duplicará a aproximadamente 3.340 en el día 37 ( 22 de febrero), se duplicará nuevamente a 6.680 en el día 50 (10 de marzo), y se duplicará nuevamente a 13.350 en el día 67 (27 de marzo). Esta es una gran cantidad de muertes, pero no tan grande como si el crecimiento fuera exponencial. Sin embargo, es mayor de lo que algunos modelos epidemiológicos han predicho.

La aparición de un exponente fraccional y el comportamiento de la ley de potencias sugiere un proceso fractal subyacente, con base en una especie de red de interacción de mundo pequeño, donde las personas tienen muchos vecinos locales y conexiones ocasionales de largo alcance (como las causadas por personas que viajan en trenes, barcos y aviones). Los resultados implican que esta red tiene una dimensión fractal de trayectoria mínima efectiva de 2,25. Esto implica que la enfermedad produce picos en los que el crecimiento es momentáneamente exponencial, pero luego se ralentiza hasta otro pico. El efecto promedio de este crecimiento aparentemente produce una ley de potencias.

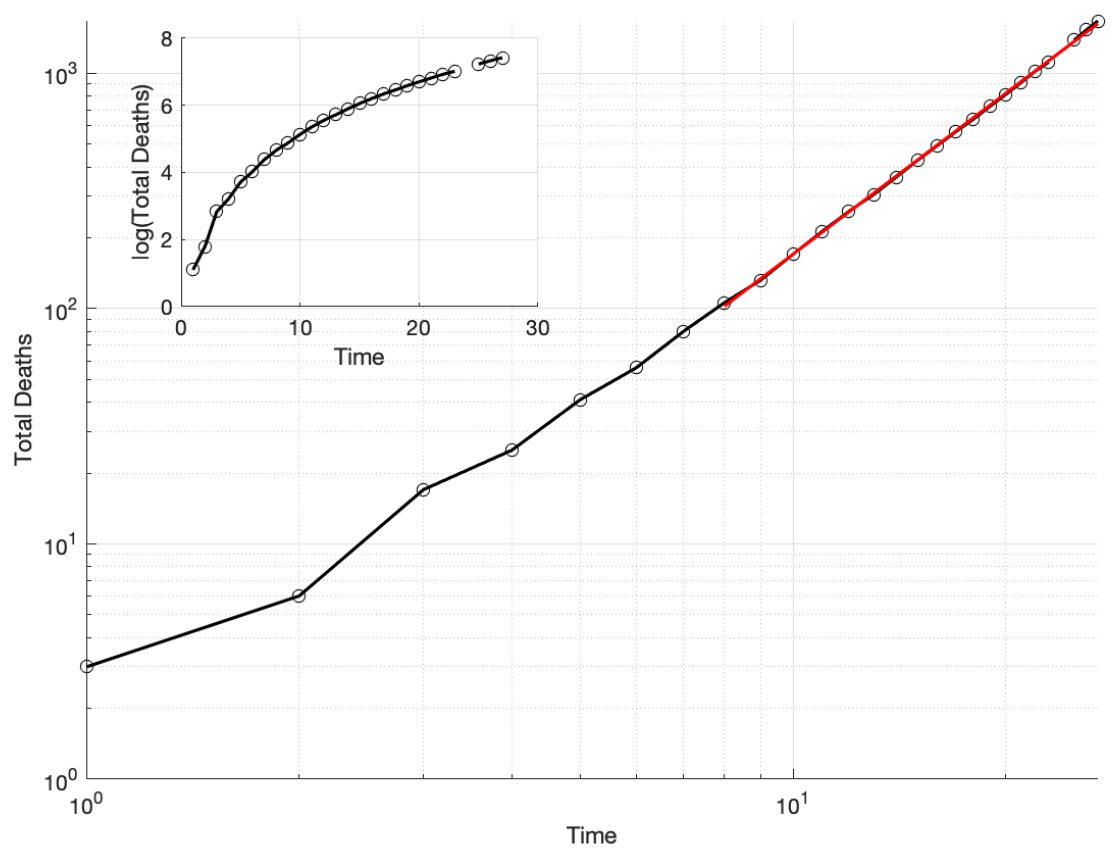

Figura 2. Muertes totales en función del tiempo, en días, desde el 21 de enero de 2020 en escalas logaritmica (principal) y semilogarítmica (insertada). Nota: la línea roja de la gráfica principal corresponde a la ley de potencias $t$ para los períodos 8-27, omitiendo el 24, es decir, del 28/01/2020 al 15/02/2020, sin tener en cuenta los datos espurios para el 2/13/2020. Datos de la World Health Organization (2020). 
Wu y otros (2020) sugieren que si la pandemia se extiende a nuevas ciudades, se produciría un crecimiento exponencial como el que ocurrió en Wuhan en las primeras fases. No obstante con suerte, si este fuera el caso, sería rápidamente detenida y se produciría un comportamiento más lento. Sin embargo, la predicción que ofrecemos de aproximadamente 13.350 muertes para el 27 de marzo se basa en el supuesto de que no ocurrirá un nuevo brote importante. Hermanowicz (2020) y Roosa et al. (2020) han modelado recientemente la enfermedad utilizando un modelo logístico y otros modelos de crecimiento. Estos modelos son capaces de predecir el número máximo de casos y resultados en el rango de 20.000 a 60.000. Creemos que los números serán mucho mayores, y el número de muertes caiga dentro de este rango, si el crecimiento fractal continúa como lo ha hecho durante unos meses más.

Hemos seguido nuestra predicción durante varios días y no hemos encontrado ningún cambio marcado en el comportamiento, a excepción de los datos del WHO Situation Report \#24, en donde se dio un salto descomunal de 254 casos a un total de 1.369 muertes. Los informes indicaban que los datos de China eran incorrectos ese día debido al doble recuento de resultados, pero las discrepancias observadas llevaron a la WHO a solicitar una revisión de las cifras. Puede observarse la gran desviación en nuestra predicción, de hecho nos llevó a sospechar que esos datos eran atípicos en ese momento.

En los últimos días se ha producido una disminución del crecimiento de nuevos casos confirmados en China, lo que sugiere una atenuación de la pandemia. No vemos esa caída en la tasa de mortalidad. Hay dos posibles explicaciones para esta discrepancia: (1) el número de casos confirmados puede estar mostrando la variabilidad como lo ha hecho en el pasado, y las cifras actuales no reflejan la situación real, o (2) la pandemia está efectivamente disminuyendo, pero tomará un tiempo (tal vez una semana) para que eso aparezca en los datos de fatalidad. Por supuesto, esperamos que esto último sea el caso, pero no estamos totalmente seguros, considerando la historia de los problemas de notificación relativos a esta pandemia.

Las desviaciones por encima de este comportamiento de ley de potencias podrían indicar que la pandemia se está expandiendo desde el actual nivel de control, mientras que las desviaciones por debajo pueden indicar que la enfermedad está empezando a desvanecerse. Los datos del brote de COVD19 todavía son preliminares y no bastan para predecir la duración del brote ni la fatalidad final. No obstante, la tendencia observada parece indicar que, en las condiciones actuales, el crecimiento siguiendo una ley de potencias se aproxima mejor al número de muertes que el crecimiento exponencial, y puede proporcionar una herramienta para monitorizar si está teniendo lugar un cambio de tendencia.

Nota: los autores informan que no ha habido una financiación relacionada con esta investigación ni, con ello, intereses en conflicto. 


\section{Appendix. Statistical Testing}

La tabla 1 enumera los coeficientes estimados de la regresión de muertes $=\beta_{0}+\beta$ 1time $+\beta_{2}$ time ${ }^{2}+\varepsilon$, donde $\varepsilon$ se supone que es independiente del tiempo y se distribuye normalmente. Informamos también de los errores estándar entre paréntesis, que son más conservadores en este contexto de una muestra pequeña. Véase Efron y Tibshirani (1994) y Horowitz (2001) para las introducciones al método bootstrap.

En la Fig. 3, los intervalos de confianza se calculan de la siguiente manera. En primer lugar, se calculan los errores estándar robustos para tener en cuenta la heteroesquedasticidad. Estos errores estándar son más conservadores, lo que resulta ventajoso para compensar el tamaño reducido de nuestra muestra. A continuación, calculamos el valor crítico (el $95^{\circ}$ cuantil) a partir de una distribución $t$ con $n-2$ grados libres. El valor $n$ cambia con cada punto a lo largo del eje $x$. A medida que se consideran menos períodos, el valor crítico aumenta. Los grados libres son una función de $n$, pero restando dos para tener en cuenta el hecho de que se estiman dos parámetros $\left(\beta_{0}, \beta_{l}\right)$. Los errores estándar son insignificanes para estos cálculos. Si se consideran los períodos 2-27 se obtiene un error estándar bootstrapeado de 0,033, utilizando 5.000 replicacioness de bootstrap.

La figura 4 muestra los exponentes estimados de la ley de potencias a partir del período 8 y añadiendo más períodos en adelante. Refleja elproceso de prueba de este modelo a medida que se publicaron más datos sobre el número de muertes. El coeficiente es estable. Los intervalos de confianza se calculan de forma análoga a los de la Fig. 3. Repárese en que los datos en el período 24 se omiten debido a la probable inexactitud, como discutimos anteriormente.

\begin{tabular}{lc}
\hline Time & 1.954 \\
& $(4.065)$ \\
& {$[4.504]$} \\
Time $^{2}$ & $2.123^{* * *}$ \\
& $(0.122)$ \\
& {$[0.132]$} \\
Constant & -39.46 \\
& $(23.84)$ \\
& {$[29.23]$} \\
\hline Observations & 36 \\
$R^{2}$ & 0.996 \\
\hline
\end{tabular}

Tabla 1. Estimaciones de un modelo cuadrático de muertes.

Nota: Los errores estándar paramétricos están entre paréntesis, los errores estándar entre paréntesis están entre corchetes. Realizamos 5.000 réplicas. Datos de World Health Organization (2020). $*(\mathrm{p}<0.05), * *(\mathrm{p}<0.01), * * *(\mathrm{p}<0.001)$. 


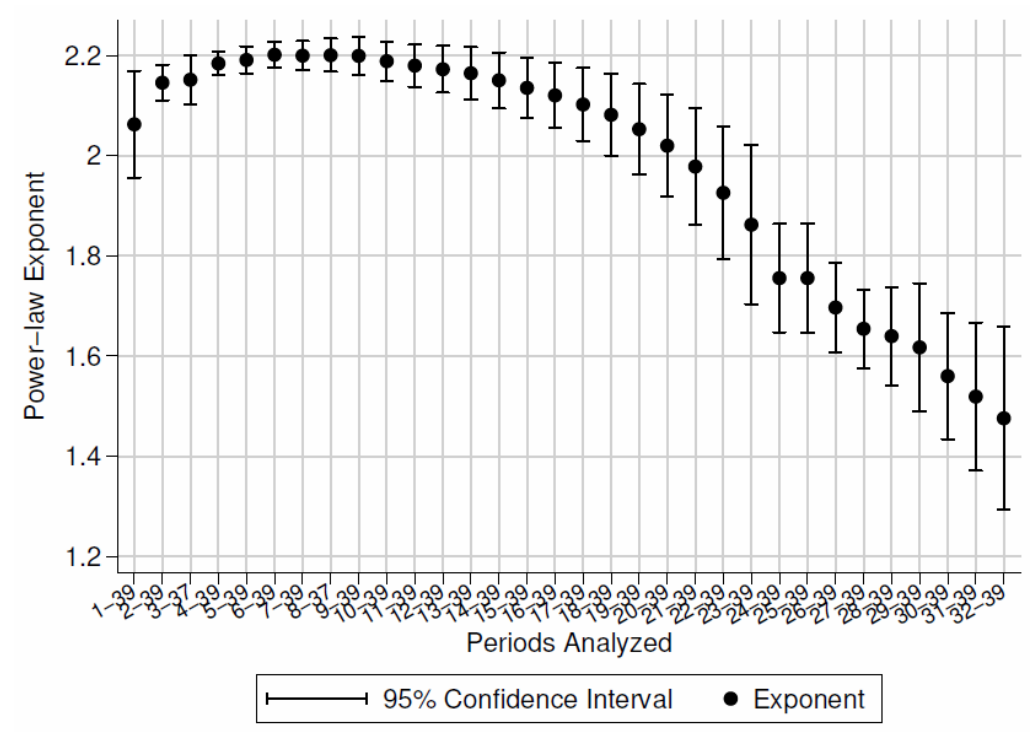

Figura 3. Coeficientes de la ley de poder, reduciendo los periodos anteriores.

Nota: los coeficientes son las estimaciones ordinarias de mínimos cuadrados de $\beta_{1}$ en el registro de regresión (Muertes) $=\beta_{0}+\beta_{1} \log ($ time $)+\varepsilon$ donde $\varepsilon$ no se observa y se supone que es independiente del tiempo, según una distribución $t$ con $n-2$ grados libres. Se calculan errores estándar robustos para una inferencia sugerida, considerando el tamaño reducido de la muestra. Datos de la World Health Organization (2020).

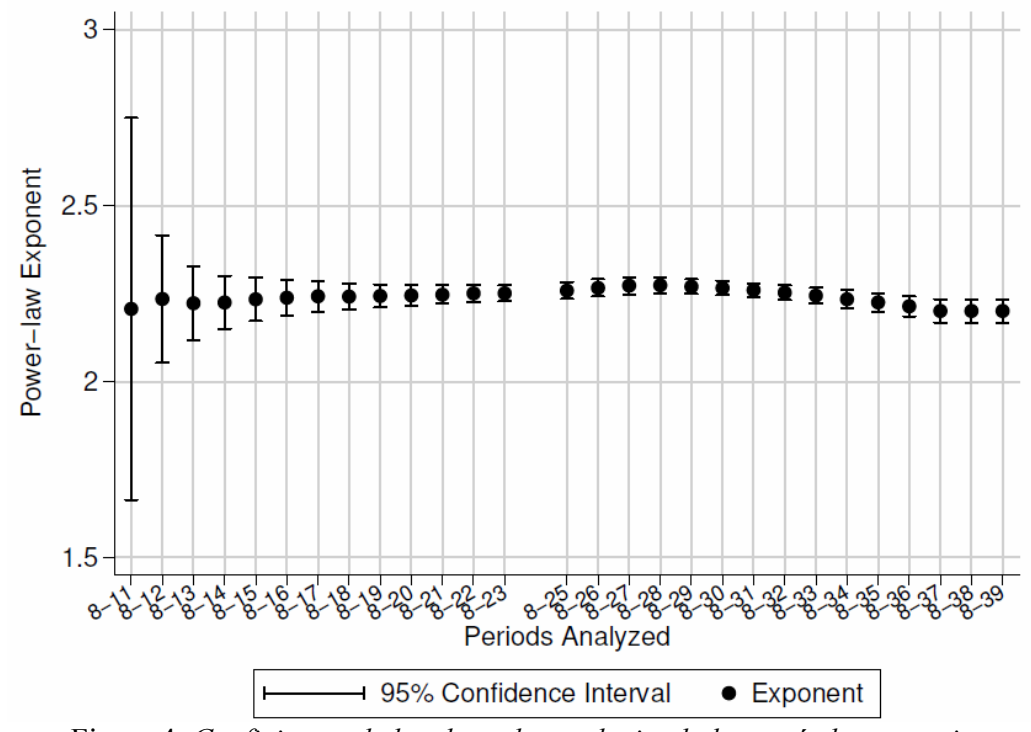

Figura 4. Coeficientes de ley de poder, reduciendo los períodos posteriores.

Nota: los coeficientes son las estimaciones ordinarias de mínimos cuadrados de $\beta 1$ en el registro de regresión(Muertes) $=\beta_{0}+\beta_{1} \log ($ time $)+\varepsilon$ donde $\varepsilon$ no se observa y se supone que es independiente del tiempo, según una distribución t con $n-2$ grados libres. Se calculan errores estándar robustos para una inferencia sugerida, considerando el tamaño de la muestra. Datos de la World Health Organization (2020). 


\title{
Actualización 01/03/20
}

\section{Cinética fractal de la pandemia COVID-19}

\begin{abstract}
Actualización] Ofrecemos una actualización al documento original realizado el 17/02/20. Ahora, a 01/03/20, el número de muertes en China ha experimentado una rápida disminución, lo que se adaptaría bastante bien a un decrecimiento exponencial de la ley de potencias similar al predicho por el modelo de red de Vázquez (2006). Al mismo tiempo, vemos que las muertes fuera de China aumentan rápidamente, $\mathrm{y}$ de un modo similar al comportamiento temprano de las estadísticas de China. Por lo tanto, vemos tres etapas de la propagación de la enfermedad en términos de número de muertes: crecimiento exponencial, comportamiento como una ley de potencias y posterior disminución exponencial.
\end{abstract}

Desde la investigación inicial presentada este artículo el 17 de febrero (que dejamos intactos a continuación para su comparación), la epidemia afortunadamente se ha desacelerado mucho en China, y el número actual de muertes allí es de $2.873(01 / 03 / 20)$. A la vez, el número de muertes fuera de China (igual a 104) está creciendo muy rápidamente, casi de manera exponencial. Así, ahora separamos los casos de China de los que no lo son.

En la Fig. 5 hay un registro de las muertes en China, mostrando un ajuste del comportamiento de la ley del poder que vimos antes, adecuado para los días $1 / 28$ a $2 / 16$. Se puede ver que la ley de potencias que vimos antes continuó durante unos días más hasta aproximadamente $2 / 20$, en cuyo momento la mortalidad comenzó a disminuir notablemente. En la Fig. 6 mostramos el número de muertes en China cada día, ahora trazadas en un gráfico logarítmico lineal, y vemos un corte brusco durante la última semana.

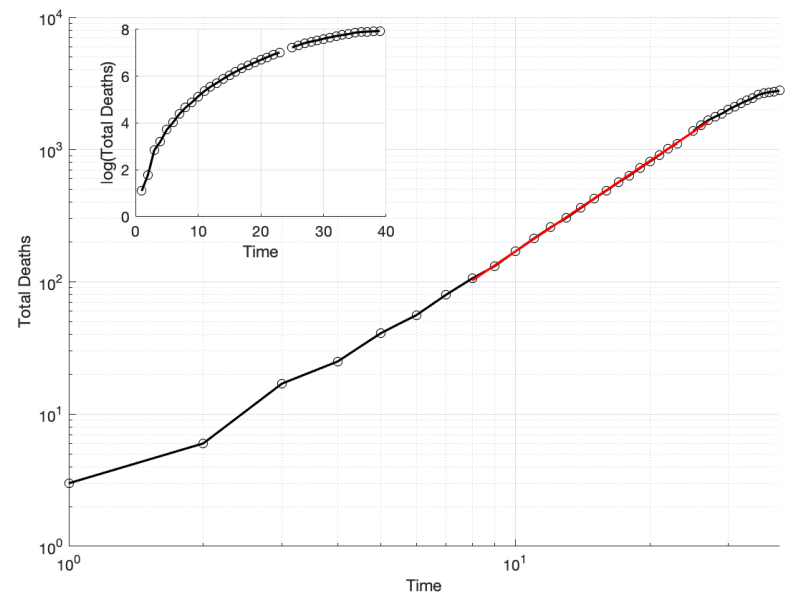

Figura 5. Muertes en China vs. Tiempo (dias desde el 21/01) en un diagrama logarítmico), y (está inserto) en un diagrama logarítmico lineal. 
Anna L. Ziff \& Robert M. Ziff, International Journal of Educational Excellence, (2020) Vol.

6, No. 1, 43-69. ISSN 2373-5929

DOI: $10.18562 /$ IJEE.053

La línea se ajusta a través de los puntos indicados en rojo, desde el día 8 (28/01) hasta el día 27 (16(02). Datos: World Health Organization (2020).

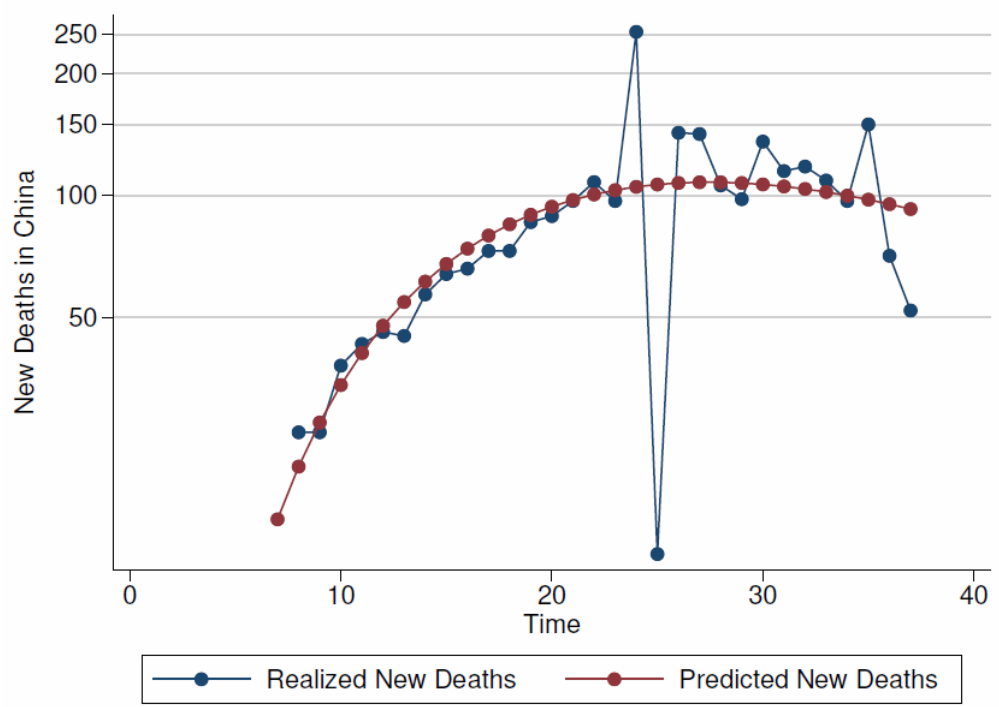

Figura 6. El número diario de muertes en China vs. Tiempo (dias desde 21/01/2020) en una gráfica logarítmica lineal.

Las nuevas muertes pronosticadas se ajustan utilizando las estimaciones indicadas en la tabla 2. Datos: World Health Organization (2020).

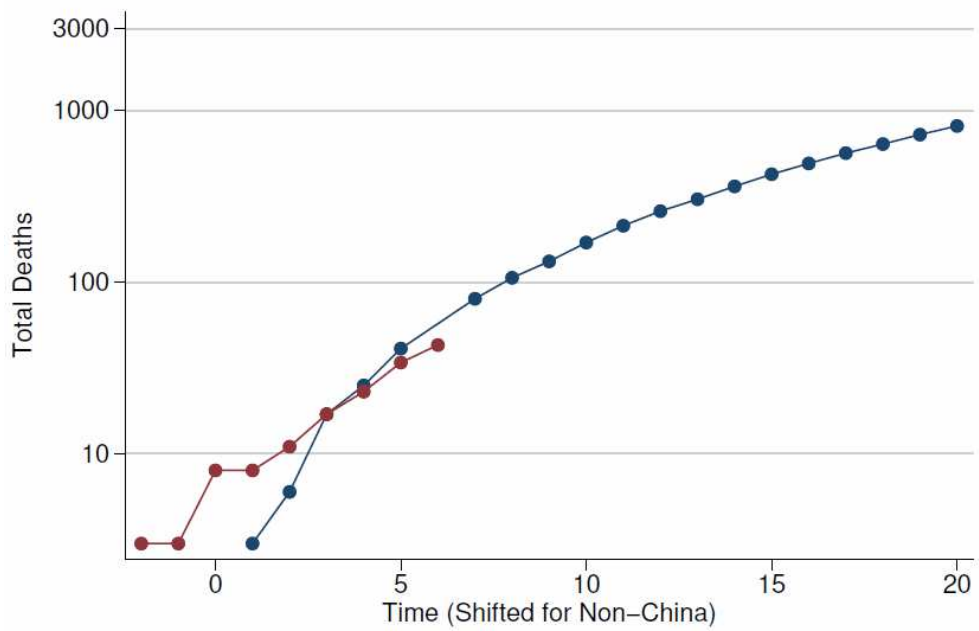

Figura 7. Muertes totales vs. Tiempo, China y fuera de China en un diagrama logarítmico lineal 
Para alinear las tendencias, restamos 31 del tiempo de los puntos de datos de fuera de China. Datos de la World Health Organization (2020).

El comportamiento de la ley de potencias (fractal) que postulamos está relacionado con las propiedades de las redes que llevan a cabo la propagación de la enfermedad. Vázquez (2006) desarrolló un modelo de red en el que el número diario de nuevos casos $n(t)$ en una epidemia sigue una ley de potencias con un corte exponencial:

$$
n(t)=K t^{x} e^{-t / t_{0}}
$$

Hemos ajustado los datos de las muertes en China a esta función y se obtiene que $K=0,0854, x=3,09$, y $t_{0}=8,90$ días (la constante de tiempo de la decadencia). El ajuste de estos datos se muestra en la Fig. 6. Obsérvese que el exponente $(3,09)$ es algo superior al valor 2,28 que se obtenía para el ajuste mediante una ley de potencias simple. La expresión anterior puede integrarse para encontrar el número total de muertes en función del tiempo, en términos de la función Gamma $\Gamma(\mathbf{x})$ y la función Gamma incompleta $\Gamma(a, x)$ :

$$
N(t)=\int_{0}^{t} n(u) d u=K t_{0}^{1-x}\left(\Gamma(x+1)-\Gamma\left(x+1, \frac{t}{t_{0}}\right)\right)
$$

Este gráfico se muestra en la Fig. 6, y vemos que encaja bastante bien con los datos. Con posterioridad a la crisis China, se observó un rápido crecimiento en el número de muertes en el exterior. Dicho crecimiento fue exponencial, duplicándose cada dos o tres días, pero tras un cierto período mostró signos de desaceleración (aunque, de nuevo, existen dudas acerca de la exactitud de los datos ofrecidos por uno de los principales puntos críticos, Irán). En la Fig. 7, mostramos una gráfica semilogarítmica de las muertes de los últimos 6 días, junto con las muertes en China desplazadas 31 días. Se constata un comportamiento algo similar, aunque con menor velocidad. Es cierto que no se puede predecir ningún comportamiento final para este evolución, pero es de esperar que, siguiendo la tendencia observada en China, pronto entre en un crecimiento como ley de potencias, antes de llegar a las etapas finales.

Tampoco es descartable que, a raíz de los viajes internacionales normales durante los meses de diciembre y enero, el virus se haya extendido a muchas partes del mundo y no haya sido diagnosticado adecuadamente. De este modo, es posible que surjan nuevos focos en diferentes lugares del mundo. Pero con suerte, con una mejor comprensión y apreciación de la enfermedad, y respuestas apropiadas, cabe la esperanza de que los nuevos focos sean contenidos y se pueda evitar un escenario de pandemia global. 
Desde que escribimos nuestro artículo (y también antes), numerosos trabajos han aparecido modelando la epidemiología de la enfermedad. Li y otros (2020) confirman el comportamiento de la ley de pontencias que propusimos para las muertes en China, y también lo encuentran (pero con diferentes exponentes) para el número de infecciones y el número de recuperaciones. Ajustando el número de casos a una cuadrícula en el diagrama de registro, predijeron un final efectivo de la epidemia alrededor del 3 de marzo con un total de 83.000 casos, lo que hasta ahora se ha cumplido.

Numerosos trabajos han considerado modelos de compartimentos y otros métodos para modelar la evolución de la epidemia Li (2020), Gamero et al. (2020), Rabajante (2020), Li y Feng (2020), Peng et al. (2020), Chen et al. (2020), Hu et al. (2020), Maier y Brockmann (2020), Li et al. (2020), Zhou et al. (2020), Xu et al. (2020), Liu et al. (2020). Tienden a predecir una curva en forma de $\mathrm{S}$ con una disminución en un futuro cercano como se está viendo. Estos modelos dependen de los supuestos de la tasa de reproducción, el período de incubación, etc.

Los autores agradecen a Greg Huber, Ginestra Bianconi y Youjin Deng por los diálogos y comunicaciones relacionadas con este trabajo.

\section{Referencias}

BBC (2020). Coronavirus: "Way too early” to predict end of outbreak, WHO says, February 2020. Recuperado de https://www.bbc.com/news/worldasia-china-51482994.

Brandenburg, A. (2020). Quadratic growth during the 2019 novel coronavirus epidemic. arXiv:2002.03638 [q-bio], February 2020. Recuperado de http://arxiv.org/abs/2002.03638.

Chen, B., Shi, M., Ni, X., Ruan, L., Jiang, H., Yao, H., Wang, M., Song, Z., Zhou, Q., y Ge. T. (2020). Data Visualization Analysis and Simulation Prediction for COVID-19. arXiv:2002.07096 [physics, q-bio], February 2020. Recuperado de http://arxiv.org/abs/2002.07096.

Cohen, J. (20200). Scientists are racing to model the next moves of a coronavirus that's still hard to predict, February 2020. Recuperado de https://www.sciencemag.org/news/2020/02/scientistsare-racing-model-next-moves-coronavirus-thats-still-hard-predict.

Efron B., y Tibshirani, R. J. (1994). An Introduction to the Bootstrap. Boca Ratón, FL: CRC Press.

Gamero, J., Tamayo, J. A., y Martinez-Roman, J. A. (2020). Forecast of the evolution of the contagious disease caused by novel coronavirus (2019nCoV) in China. arXiv:2002.04739 [q-bio, stat], February 2020. Recuperado de http://arxiv.org/abs/2002.04739. arXiv: 2002.04739. 
Hermanowicz, S. W. (2020). Forecasting the Wuhan coronavirus (2019$\mathrm{nCoV}$ ) epidemics using a simple (simplistic) model - update (Feb. 8, 2020). Epidemiology, In Press, February 2020. doi: 10.1101/2020.02.04.20020461 Recuperado de http://medrxiv.org/ lookup/doi/10.1101/2020.02.04.20020461.

Horowitz, J. L.. (2001). The Bootstrap. In S. Durlauf, L. Hansen, J. Heckman y R. Matzkin (ed.), Handbook of Econometrics, volume 5, (pp. 31593228). New York: Elsevier, doi: 10.1016/S1573-4412(01)05005-X. Recuperado de https://linkinghub.elsevier.com/retrieve/pii/S157344120 $105005 X$.

Hu, Z., Ge, Q., Jin, L., and Xiong, M. (2020). Artificial Intelligence Forecasting of Covid-19 in China. arXiv:2002.07112 [q-bio], February 2020. Recuperado de http://arxiv.org/abs/2002.07112.

Li, J. (2020). A Robust Stochastic Method of Estimating the Transmission Potential of 2019-nCoV. arXiv:2002.03828 [physics, q-bio, stat], February 2020. Recuperado de http://arxiv.org/abs/2002.03828.

Li, M., Chen, J., y Deng, Y. (2020). Scaling features in the spreading of COVID-19. arXiv:2002.09199 [physics, q-bio], February 2020. Recuperado de http://arxiv.org/abs/2002.09199.

Li, Q. y Feng, W. (2020). Trend and forecasting of the COVID-19 outbreak in China. arXiv:2002.05866 [q-bio], February 2020. Recuperado de http://arxiv.org/abs/2002.05866.

Liu, Z., Magal, P., Seydi, O., and Webb, G. (2020). Predicting the cumulative number of cases for the COVID-19 epidemic in China from early data. arXiv:2002.12298 [math, q-bio], February 2020. Recuperado de http://arxiv.org/abs/2002.12298. arXiv: 2002.12298.

Maier, B. F., y Brockmann, D. (2020). Effective containment explains subexponential growth in confirmed cases of recent COVID-19 outbreak in Mainland China. arXiv:2002.07572 [physics, q-bio], February 2020. Recuperado de http://arxiv.org/abs/2002.07572.

Peng, L., Yang, W., Zhang, D., Zhuge, C., y Hong, L. (2020). Epidemic analysis of COVID-19 in China by dynamical modeling. arXiv:2002.06563 [q-bio], February 2020. Recuperado de http:// arxiv.org/abs/2002.06563.

Rabajante, J. F. (2020). Insights from early mathematical models of 2019$\mathrm{nCoV}$ acute respiratory disease (COVID-19) dynamics. arXiv:2002.05296 [q-bio], February 2020. Recuperado de http://arxiv.org/abs/2002. 05296. arXiv: 2002.05296.

Roosa, K., Lee, Y., Luo, R., Kirpich, A., Rothenberg, R., Hyman, J. M., Yan, P., y Chowell G. (2020). Real-time forecasts of the 2019-nCoV epidemic in China from February 5th to February 24th, 2020. Infectious Disease Modelling, February 2020. doi: 10.1016/j.idm.2020.02.002. 
Recuperado de https://linkinghub. elsevier.com/retrieve/pii/S2468042 720300051.

Vázquez. A. (2006). Polynomial growth in age-dependent branching processes with diverging reproductive number. Physical Review Letters, 96(3), 038702, Recuperado de http://arxiv.org/abs/condmat $/ 0505116$.

Wang V. (2020). How Many Coronavirus Cases in China? Officials Tweak the Answer, February 2020. Recuperado de https://www.nytimes.com/ 2020/02/12/world/asia/china-coronavirus-cases.html.

World Health Organization. Novel Coronavirus (2019-nCoV) situation reports. Technical Report 1-24, WHO, January 2020. Recuperado de https://www.who.int/emergencies/diseases/novel-coronavirus-2019/ situation-reports.

Wu, J. T., Leung, K., y Leung, G. M., Nowcasting and forecasting the potential domestic and international spread of the 2019-nCoV outbreak originating in Wuhan, China: a modelling study. The Lancet, In Press, January 2020. doi: 10.1016/S0140-6736(20)30260-9. Recuperado de https: //linkinghub.elsevier.com/retrieve/pii/S0140673620302609.

Xu, X., Jiang, X., Ma, C., Du, P., Li, X., Li, S., Yu, L., Chen, Y., Su, J. Lang, G., Li, Y., Zhao, H., Xu, K., Ruan, L., y Wei, W. (2020). Deep Learning System to Screen Coronavirus Disease 2019 Pneumonia. arXiv:2002.09334 [physics], February 2020. Recuperado de http://arxiv.org/abs/2002.09334. arXiv: 2002.09334.

Zhao, S., Lin, Q., Ran, J., Musa, S., Yang, G., Wang, W., Lou, Y., Gao, D., Yang, L., He, D., y Wang, M. H. (2020). Preliminary estimation of the basic reproduction number of novel coronavirus $(2019-\mathrm{nCoV})$ in China, from 2019 to 2020: A data-driven analysis in the early phase of the outbreak. International Journal of Infectious Diseases, In Press, January 2020. doi: 10.1016/j.ijid.2020.01.050. Recuperado de http://www.sciencedirect.com/science/article/pii/ S1201971220300539.

Zhou, Y., Chen, Z., Wu, X., Tian, Z., Cheng, L., y Ye, L. (2020). The Outbreak Evaluation of COVID-19 in Wuhan District of China. arXiv:2002.09640 [physics, q-bio], February 2020. Recuperado de http://arxiv.org/abs/2002.09640.

(C) 2020 A. L. Ziff \& R. M. Ziff; licensee International Journal of Educactional Excellence, Universidad Ana G Méndez (UAGM). This is an Open Access article distributed under the terms of the Creative Commons Attribution License (http://creativecommons.org/licenses/by/4.0), which permits unrestricted use, distribution, and reproduction in any medium, provided the original work is properly credited. 